\title{
Emergenza migranti: from metaphor to policy
}

Federico M. Federici

The biased, conditioning, and aggressive metaphor of emergenza migranti altered not only the perception of the arrival of migrants onto Italian harbours but also the linkage between the journalistic and political narrative, and the legislative actions justified by it. The bias became so extreme that United Nations High Commissioner for Refugees (UNHCR) called journalists to develop an ethical stance in reporting about migration (see discussion below) so as to oppose the debasement of journalistic standards in favour of sensationalist figurative language. With its widespread adoption in the national press in Italy, the metaphor has become a political tool to justify incomplete policies of migration at national (and to some extent international) level. Unparalleled numbers of people have become forced migrants in the last decade (over 65 million, according to UNHCR, 2017); a decade in which countries that were migrants' destinations were afflicted by the worst economic crisis in decades. In the sections to follows, this chapter argues that the deliberate choice of specific language is the manifestation of political agendas and it then becomes further cause for misplaced perceptions of migration flows in Italy. The powerful language affected the political debate in Italy culminating with the legislative changes introduced by the Decree of Law 113/2018, 5 October 2018 (the Salvini Act). The decree restricts applications for Italian citizenship (Art. 14) and applications for asylum (Art. 12), thus confirming the success of the hard-line right wing, semi-fascist coalition in power. 
This chapter considers three dimensions of the skewed perceptions reinforced by the emergenza migranti metaphor: 1) the journalistic risk of endorsing a narrative frame over a long period of time; 2) the limitations of 30 years of Italian policies dealing with migratory flows as a contextual justification for embedding the discursive metaphor into legislative and political practices; 3) the shortcomings of letting the perceived migrants' emergency drive plans for intercultural communication, when it really deals with a crisis scenario. Subdivided into three sections, the chapter suggests provocative interpretations of the impact of the collocation emergenza migranti. Firstly, the phrase and its uses are discussed within the context of the movement for an ethical journalism, which upholds reporting values to protect the credibility of journalism. Secondly, the text argues that the discussion of news reliability has created a powerful and confusing form of oblique censorship, which makes extremist soundbites like emergenza migranti successful as useful and sloppy shortcuts against complex debates. Thirdly, it considers the social impact of these defective narrative shortcuts by reviewing Italian migration policies, which also focus on intercultural communication among a growing multilingual and multicultural society to support gradual integration of speakers of languages other than Italian. In the final remarks those three dimensions are brought together.

\subsection{Code of conduct vs raging metaphors}

This chapter is a thought contribution and is grounded on over ten years of observations and interpretations of the Italian news-making context discussed in master-level classes and at conferences. I have focus on the ways in which Italian journalism has used recognizable national frames to introduce - via translated materials - information about 'the Other', more specifically the foreigner. In the 2010s, new migrant flows exacerbated the forms of national framing taking some extreme examples of vulgar, hatred-filled headlines (see Filmer, 2018, p. 
166). These extreme reactions blossomed around such figures of speech as invasion and emergency.

Their power was so devious that the journalistic response to the phenomenon of displacement took such a negative framing that attracted the attention of the United Nations High Commissioner for Refugees (UNHCR) in 2013. Also, Italian associations of journalists began to call for adhesion to principles of the Ethical Journalism Network (EJN). The EJN is an international network that draws on self-reflection and analysis of journalistic practices since 2011 - coinciding with the most profound investigation of journalistic practices of the British press, the Leveson Inquiry (2011-2012). At that time, following the initial socialchanges driven by the Arab Spring, the wars in Iraq, Afghanistan, and the many forgotten wars in Africa, Mediterranean countries and the EU began experiencing increased migratory flows. The unprecedented numbers of displaced people in the early 2010s, confused with the movement of people across European members states, had fuelled an anti-migrant narrative. Journalists' reporting practices led to highly divisive civil societies in Europe. Until some journalists decided to take a step back and look at ongoing practices.

In Italy, the National Council of the Journalists' Association (CNOG) and the Italian National Press Federation (FNSI), sharing the UN concerns, saw the need to articulate a new charter of deontological behaviour the Charter of Rome (2014). The Charter focuses entirely on reporting about the so-called migrant crisis for professional journalists and is a protocol in addition to the existing Italian Journalist's Charter of Duties, or code practice (Carta dei doveri del giornalista). The very fact that this document is an addition to the Charter of Duties indicates the seriousness of the association's concerns.

The Charter calls journalists to 'exercise the highest' care when they report on migration-related news items (2014: 1). They should do so by upholding four principles: a) using appropriate terminology - as defined by the UN, 'asylum seekers, refugees, victims, of 
trafficking and migrants' (see also discussion in Čemerin chapter in this volume), b) avoiding 'spreading, inaccurate, simplified or distorted information as regards the latter groups'; c) safeguarding their confidentiality in interviews; 4) consulting 'experts and organisations with a specific expertise on the subject so as to provide the public with information which is clear, comprehensive and also analyses the underlying roots of phenomena' (2014: 1).

However, the narrative framing of the arrivals of migrants in Italy as an 'emergency' had been long established by the time of the Charter of Rome. That framing obviously influenced the respective readerships and audiences but also political debates and legislationnot only in Italy, even though this chapter only focuses on the Italian contexts. Political debates and legislation were informed by the enduring, skewed perception. This influence led to confusing definitions of needs (between migrants, refugees, and asylum seekers) and of support in establishing communication with the relevant Italian authorities - thus engendering a real crisis in terms of intercultural communication.

This chapter does not underestimate that the sheer number of arrivals was unprecedented during the 2014-2016 peak years of the refugee 'crisis' - following the EU definition of the phenomenon. Although the issue of scale was a legitimate concern that could have had an impact on the most robust and solid plans to deal with displaced people, behind the emergency framing, successive Italian governments had hidden the embedded behaviour of Italian politicians to ignore its own established policies and common theoretical planning, in favour of last-minute, ad-hoc approach to highly predictable events (the Decree of Law $113 / 2018$ represents only the last in line in this responsive legislation, which does not engage with the long-term but only the immediate political and electoral gain). The press representation of human-made disasters and conflicts leading to large displacements of people, with the subsequent migration streams towards European countries in 2011-2016, goes beyond the Italian context, However, arguably, the Italian press chose very specific words that 
warranted a focus on the exceptionality of the phenomenon rather than an ethical representation of the many phenomena converging into the mass displacement of people.

In a strange parallelism, the framing construed around the emergenza metaphor resembles press depictions of semi-predictable environmental disasters, for which Button (1999: 114) reminds us of 'how the media packages information and participates in the construction of reality and informs us of the ideological elements that work to maintain the status quo in the wake of a disaster'. By defining it an emergenza, nobody can mitigate its impact, as if the factors causing the displacement of people were not known. A further challenge emerged through the long-term humanitarian crises driven by conflicts and their cascading effects (Pescaroli \& Alexander, 2015), because these effects showed up ineffectual solutions to the reception of migrants and the processing of applications for EU residence, via the Italian system. The frame of emergenza heightens the sense of unpredictability, which arguably was not an element in the migration crisis of the second decade of the $21^{\text {st }}$ century.

\subsubsection{Ethics and Journalistic frames of representation}

The group of editors and journalists who funded and collaborate to the Ethical Journalism Network (EJN) collected analyses of reporting on migration in the Mediterranean. In 2017, they conducted a large scale-study upon commission by the EUROMED Migration IV project ${ }^{1}$, in collaboration with the International Centre for Migration Policy Development (ICMPD, founded in 1993). Entitled How does the media on both sides of the Mediterranean report on migration? (2017), their study solicits serious reflections on reporting across Europe. Within this context, Masera (2017: 46-52) focused on Italy and provided evidence of the ways in which

\footnotetext{
${ }^{1}$ The overall objective of the project is to support EU Member States and ENI Southern Partner Countries in establishing a comprehensive, constructive and operational framework, with a particular focus on developing evidence-based and coherent migration policies and activities. (ICMPD online, https://www.icmpd.org/ourwork/migration-dialogues/euromed-migration-iv/).
} 
the tones used by the Italian press have changed over the last two decades. Their exacerbation and hyper-sensationalised undertones came under scrutiny when the 2013 tragedies in the Mediterranean brought about a revision of practices. The change of the tones used by most other Italian media, according to the study, was noticeable in 2016 and 2017. Of course, extreme right-wing and right-wing outlets continued with their excessive and surcharged discourses. For instance, Il Giornale and Il Fatto Quotidiano famously used invasione invasion - as the favourite term to discuss the arrival of migrants on Italian shores. The emergenza migranti, through the rhetoric of the right-wing, racist Northern League party and its representative in the role of Ministry of Interior within the coalition government, perpetuate the metaphor through an aggressive (and for some illegal) anti-migration policy. The facts and figures tell a different story (see OECD 2018) but the narrative frame remains difficult to challenge. Undeniably, a ten-year-long plethora - if not outright bombardment - of repeated uses of figures of speech, firmly embedded in the political parlance by the right-wing coalition government led by Prime Minister Silvio Berlusconi from 2008, cannot be undone in lustre.

\subsubsection{Daily newspapers: La Repubblica, Il Corriere, and La Stampa}

By researching the online and printed archives of three major daily newspapers La Repubblica, Corriere della Sera, and La Stampa (data on national distribution was retrieved from AUDIPRESS 2018), it is possible to track the spread of the emergenza expression via the newspapers with the largest (national) readership. Their usage of the expression arguably would reflect an established framing in televised news broadcasts. Its precursor, emergenza clandestini (emergency clandestine), used in the 1990s (see discussion below), functions as a reminder of the habitual use of the noun clause emergenza+noun in the journalistic variety of the Italian language. Such clause types represented a linguistic feature of the journalistic variety in the printed press, but seamlessly transferred into its online publications (Bonomi, 2002; Eco, 
1971; Lorusso \& Violi, 2015). Consulting on corriere.it the subscription-only archives for the online and digitized printed versions of Corriere della Sera, the expression grows in significance and occurrences in the same years as it does for its competitors, but its usage seems to be less consistently present and tends to be limited to quotations. However, the Corriere della Sera archives also return a first-page heading 'Clandestini, emergenza in Sicilia' dated 3 August 1998; this was not necessarily the first occurrence for that expression, a predecessor of emergenza migranti, but it is a stern reminder of the embeddedness of the syntagma, emergenza+noun, in the journalistic variety (of Italian).

Consulting the archives of La Repubblica - via its online (subscription-only) repubblica.it services providing access to paper and digitized printed versions - the expression emergenza migranti seems to appear for the first time from mid-May 2009 as if it were a regular collocation that appears meaningful and accessible to the audience. In fact, it is not accompanied by any gloss, presuming therefore that the readers recognize this collocation. There is no evidence of any occurrence in the archived materials of Repubblica, which start 1 January 1984. Since its first recorded occurrence to 2018, there are, however, over 830 occurrences in the intervening years

The online archives of La Stampa support the perception that this newspaper became more attentive to avoiding the expression from early on. Anna Masera, the copyeditor of its main online pages, being a regular collaborator of the EJN, steered this newspaper towards a more considerate use of negative frames on the migrant crisis.

These cursory observations and findings based on rudimentary frequency scores of emergenza emigranti intend to capture the undertones in its usages. However, I would not expect these minimalistic insights on the linguistic facts do not necessarily persuade the readers that this approach would be enough to justify this interpretation of the linguistic phenomenon. As a phenomenon of usage in written press and, certainly, in broadcast (see Fig. 11.1), the 
study of this expression would require a more profound stand-alone systematic scrutiny. However, these first observations are already telling.

The purpose here is to contextualize how an expression repeated consistently almost every two days across two of the major national newspapers came to undermine political policies to deal with migration. Until the time, in 2011, when the expression itself gave way to a political use of special finances to fund the nth ad-hoc solution to engage with the migratory flows in the Mediterranean, when the expression was used to justify the declaration of a state of emergency (see Filmer and Federici, 2018). The next section shows how the political force of this framing gradually led to a legislative, rather than a political, use of the expression.

\subsection{Framing is neither new, nor surprising}

Nobody ever expects narratives from news organizations to attempt uncensored and unbiased presentation of events (Zelizer, 2015; Zelizer \& Allan, 2010). However, the exacerbation shown in 2016 and 2017 of politically-driven concepts of mistrusts on traditional journalism with the US executive giving enormous exposure to the misleading concepts of 'fake news' and 'alternative facts' boosted the growth of a new form of journalistic censorship. The focus for this chapter lies with the representative force of figurative language (Montgomery, 2008) in relation to the emergenza migranti collocation and it does not intend to be a blind attack of the press - freedom of the press is under attack in Italy, as in many other G20 countries.

Since 2016, right-wing, supremacist, and racist politicians in Italy (e.g. Salvini), the UK (e.g. Farage), and the USA (e.g. Trump) more extensively than elsewhere have been conducting attacks to esteemed members of the press. They do it when journalists ask questions that such politicians perceive difficult or irrelevant to their worldview as disjoint from the opinion of the countries they represent (composed of both those who voted for them or for other candidates). Emerging from populist contexts, and fuelled by conspiracy theories online, 
until recently reactionary political positions laid secretly at the background of G8 countries that considered themselves as democratic. Suddenly, the darkest manifestations of these reactionary positions have become a world-wide phenomenon (Slavtcheva-Petkova, 2016). Even more recently, they have been shown to pertain to the Italian context quite poignantly by investigative reports such as the one by the New York Times (Horowitz, 2017) and BuzzFeed (Nardelli \& Silverman, 2017).

Damocles' sword is ever-pending in the Italian contexts. On the one hand, the phenomenon of a 'journalism under attack' is particularly dangerous, as it has been subject of over 30 years of interference of its news system by media tycoon Silvio Berlusconi, replaced by a louder and more censoring interference by self-proclaimed beholders of all truths, the right-wing coalition of the Movimento 5 stelle (Five Stars Movement, 5SM) and the Northern League. On the other hand, journalists have been themselves responsible for enforcing and showcasing ever more inappropriate and unacceptable terms and narratives as if they are entitlement of freedom of speech. The excesses of the Italian coalition government formed in June 2018- three months after the general elections - led Mr Matteo Salvini, current Minister of the Interiors of Italy, to deny NGO boats as well as migrant boats in trouble in Italian waters access to Italian ports. The reactive action was transformed towards the end of 2018 into the Decree of Law 113/2018 that sanctioned restrictions to the conditions for asylum applications (Art. 1 and Art. 2) whilst simultaneously simplifying procedures for deportation, re-entry, and repatriation (Art. 4, 5, and 6). To reach this extreme political action, the government benefitted from the previous ten years of framing of the isolation of Italy when dealing with migratory flows, and its uniqueness in having to deal at the same time with the effects of substantial displacement movements (due to conflicts and socio-political causes) and migration streams (due to economic and personal reasons) that landed onto its shores, whilst being the 'backdoor' to Europe (Filmer and Federici 2018). 
Reflections on international journalism and its needs for credibility are becoming ever more necessary at the time of news processing by artificial intelligence (Clerwall, 2014). International journalists have discussed yet another crisis of journalism (Zelizer, 2015) from first decade of the $21^{\text {st }}$ century in which citizen journalism has seen a sudden growth (Allan 2006). The last decade and the last lustre have seen the problem emerge as a scourge of current democracies: new forms of cyber-propaganda via news tweets have appeared together with open channels that reject notions of evidence, proofs, and any concept of reliable, credible, and fact-checked sources. In this mixture, the use of coloured and negatively biased collocations such as emergenza migranti as a way of offering a transparent access to other worldviews risks being ever more skewed towards forms of oblique censorship (Federici, 2011). It could be argued that strong collocation 'migrant crisis', which is the preferred label used by the EU institutions to refer to the increased displacement of people after the Arab spring, the war in Syria, the prolonged conflict in Afghanistan since 2012, might have led to alternative perception of the phenomenon, as one in need of concerted, rationalised, and pondered solutions for the long-term, rather than a short-term, unexpected emergency.

Emergenza migranti can be plotted as a different translation solution of the different conceptualization of the phenomenon as a crisis. The EU-preferred collocation entails that the current events are due to affect people for a long time, whilst the Italian emergenza is an emergency requiring immediate and strong action with resources and response (on the differences between crisis and emergency, see Alexander, 2002, 2006; Alexander and Pescaroli 2016). Filmer and Federici (2018: 230) emphasise: 'On 7 April 2011, the then Prime Minister Silvio Berlusconi declared a "state of national emergency" due to increased migratory flows following the Arab Spring, which de facto endorsed the media discourse on "migrant emergency" by activating special governmental powers'. By interlocking people's displacement with notions of emergency that legally frame the deployment of financial 
resources in the case of natural disasters in Italy, the emergenza migranti collocation became a powerful political tool.

The next section further emphasises the political and social significance of this linguistic choice by considering it as a form of oblique censorship. Emergenza migranti becomes as metaphor that stifles political and social debates on migration routes, with the purpose of simplifying the evolution of societies in a globalised $21^{\text {st }}$ century world. Any other analysis of the migration phenomenon became secondary and attributed to buonismo (a negative connotation to describe those who keep an open-mind on social issues, rather than compartmentalize and group people; normally attributed by right-wing politicians to moderate and left-wing intellectuals and politicians). It is therefore useful to consider this concept in the next section.

\subsubsection{Conceptualization of oblique censorship}

Bunn's (2015) revisits established notions of censorship in New Censorship Theory and puts forward a very powerful argument that we should rethink censorship as relativistic forms of freedom of thought. Such conceptualization will be applied in the specific of this chapter to a relativistic form of freedom of press. For Bunn, (2015, p. 43): 'It may ultimately turn out that effective authoritative censorship is not simply external, but insinuates itself into the circuits of communication, not simply coercive but also mobilizes powerful social currents, not simply repressive but also generates new forms of speech and thought'. The conceptualization of censorship as part of a continuum within channels of communication and actors alike may appear ethically disturbing at first, yet it is a powerful instrument to investigate mass phenomena that discredit experts, science, and evidence-based (fallible but tested) notions in favour of unfounded, memetic rumours that have their main power in numbers - and hence in their easily dissemination open to easy manipulation. The linguistic roots of this political power 
if well-explained in a long Western tradition of rhetoric from the sophists, Aristotle, to Gramsci, before Bourdieu discussed it in sociological terms. To understand the actors in the linguistic process of censorship, many areas should be investigated. For Bunn (2015: 44), '[s]uch an investigation entails examining the actual practice of censors, not as external actors within a system of communicative control, but as the surprisingly undertheorized and unappreciated cogs within communication networks in which powerful forces like the state invariably operate'. Arguably, page editors choosing headlines and sub-headlines with easy collocations censored other perspectives on the migration phenomenon.

Among the many possible definitions of censorships, to Bunn I also juxtapose a pragmatic definition that Billiani. She proposed it and used it specifically to conduct research into the relationship between translation and censorship, 'Censorship itself must be understood as one of the discourses, and often the dominant one, produced by a given society at a given time and expressed through repressive cultural, aesthetic and linguistic measures or through economic means' (2007/2014, p. 2). This definition can extend into a notion of 'oblique censorship' of alternative views - for instance, seeing migratory phenomena in the context of global, socio-economical changes that lead to a long crisis until a solution is found. The rhetoric behind emergency as a choice, which diminished after the Charter of Rome, presents an example of this exclusion of ideas by omission, an oblique censorship.

The open manipulation of credibility, in smear campaigns targeted to vulnerable groups or individuals, but also in consolidated propaganda is an equally well-known historical phenomenon (see for instance Neander and Marlin 2010) and one with new permutations that is growing in significance world-wide, with increasing levels of unchallenged populistic views. However, in Italy, the demagogic forms of populism have taken specific aim to discredit both investigative journalism and the role of expertise and scientific competences. For instance, an extensive, commercially funded, and scientifically-unfounded no-vaccination (termed as 'no- 
vax') campaign - driven by the unruly and uncritical dissemination of the theory presented in the now-retracted article by Wakefield et al (1998) led the Italian government to put forward a Decree of Law (no. 73, 7 June 2017) to avoid epidemics in young children. The growth of the inconsiderate and erroneous belief that vaccinations carry higher levels of risk for individual than benefits for the public health of the population illustrates a significant issue in trusting alternative sources of journalism (Horowitz, 2017; Nardelli \& Silverman, 2017), because shortcuts taken by traditional journalism had already undermined their credibility.

The need for the Charter of Rome in 2014 proved that this fear came to be acknowledged by journalists in relation to reporting the migrant crisis. However much the trend is global and determined by circulation of rumours on social media, the Italian manifestations are particularly relevant because the current government coalition includes a party whose ideas are too often based on generic internet sources, with no fact-checking, and no scientific or rigorous backing (the $5 \mathrm{SM}$ ). Their resulting rhetoric is an incarnation of the Orwellian nightmare where serious situations that need solutions are made banal to be dismissed with extra-ordinary measures, rather than with institutional plans. The emergenza migranti encapsulates, metaphorically, the preference for ephemeral, untested, inefficient, and ineffective patchwork solutions over accepting the complexity of $21^{\text {st }}$ century and working to mould a political strategy that work towards accommodating its challenges, rather than around them. The emergenza migranti enforces a sense of intercultural emergency without an emergency plan.

A substantial number of social media accounts, ranging from blogs, Twitter, and Facebook to Instagram, support circulation of misinformation in attempts to discredit any traditional source of information in Italy. The Italian anomaly is that the largest party with the relative majority after the 2018 election seems to be reliant on entirely web-based sources. The 5SM was at its core a social media movement, grown into a party by a new typology of media 
tycoon, the webplatform owner Gianroberto Casaleggio). Born in the name of a web democracy, this party creates proselytes online by means of ill-informed news pieces controlled by a small number of individuals (not unlikely from 'traditional' or 'old' media in the hands of an invasive tycoon, who completely hide behind their internet platforms). Through control of misinformation and use of social media, they discredit science, scientists, discoveries by opposing their forms of web-based 'revealed' truths to the scientific method (to which we can still impute many limitations, but not the strive to revise, review, and reconsider theories on the ground of evidence). This political movement has created a shift in journalism happening as it did alongside the exponential growth of social media; traditional press however had been caught in this self-defeating spiral once it established its preference for loud refrains, such as emergenza migranti, as continuous simplifications of very complex situations. Over time with the financial crisis of 2007, still affecting the Italian economy, the perceived stato d'emergenza has been ingrained in the population.

In this context, a polarisation between 'old' and 'new' media has emerged in Italy stronger than other seen elsewhere, also as a result to intimidating, violent, and repeated attacks to Italian press, as Natale reminds us (2016, p. 594), 'in the rhetoric of the [Italian] 5-StarMovement, the country is seen as divided into two contrasting blocks, "one which finds information in the Web, the other which finds disinformation in newspapers and television" (Grillo, 2008)'. Most Italians access news via TV broadcasts (91.3\%, see figure below) and newspapers are the $4^{\text {th }}$ source of information, but of course their relevance combining webbased and printed access remains significant. Nevertheless, collocations usable in oral broadcasts become standard coinage in the printed and digital press, hence emergenza migranti achieved its spread because of political and televised use but was embedded in the narrative by the continued use in Italian newspapers for over 10 years. The next section expands on earlier 
critical reflections on the sematic of the misused noun emergenza (Federici 2016) in relation their significance within policy making.

Figure 11.1. Access to information in Italy

[INSERT Figure 11.1]

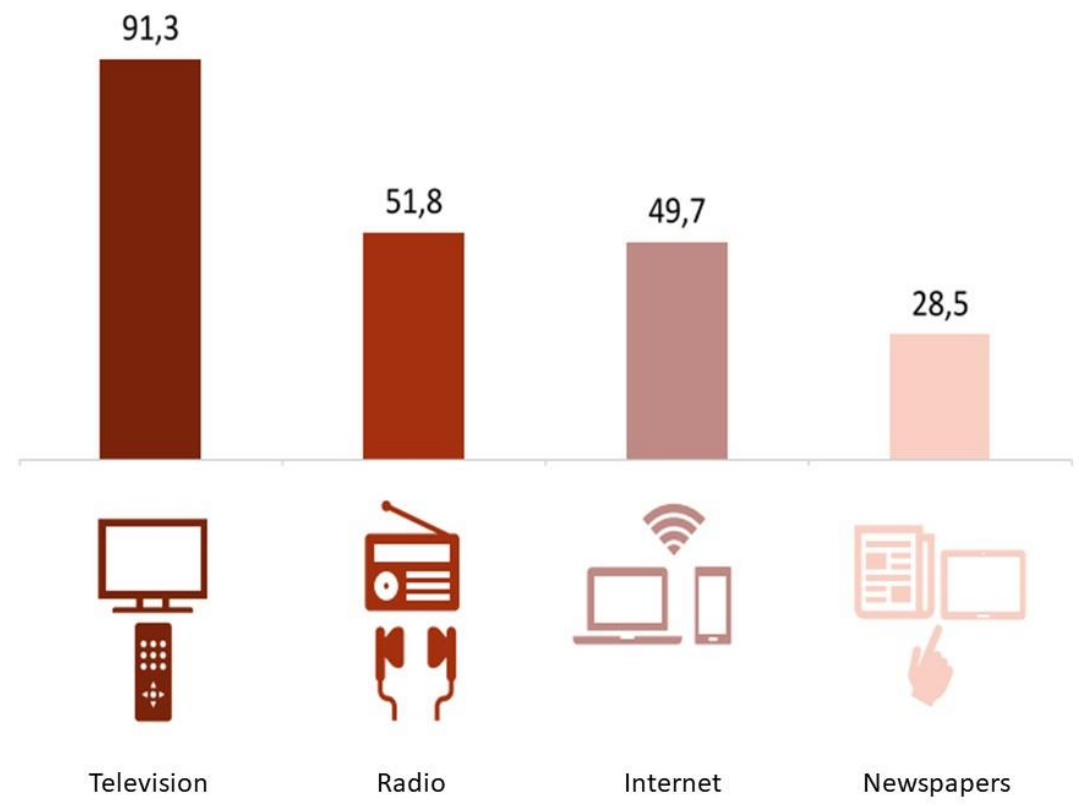

Source: Autorità per le Garanzie nelle Comunicazioni (AGCOM), Rapporto sul consumo di informazioni (AGCOM, 2018).

New approaches are documenting how difficult it is for audiences to discern information provided by credible and reliable scientific sources (McKnight \& Coronel, 2017), when alternative sources are used to corroborate discussions on polarising topics. Adaptations of news items such as the migrant crisis more ruthlessly as an emergency become means of purporting views in an instrumental way: the EU crisis becomes a catalyst point only in Italy; it becomes such a breaking point that, similarly to the onset of a disaster, foregrounds the need for immediate and urgent action, rather than a systematic approach. 
Although their content is public and visible, social media groups (on numerous platforms with diverse audiences but similar purposes, Instagram, Facebook, Twitter, and many country-specific others) do not represent an open dialogue. Conversations tend to be compartmentalised into closed bubbles, cyclically dialoguing within closed, exclusive communities. Social media-based exchanges are even more closed in-group conversations than traditional media in as much as they use polarised forms of dialogue. Soundbites like emergenza migranti amass in the faceless cauldron of rage that is Twitter. And even when the real peak of 'going viral' for the bitesize phrase and sentence phenomenon is over (see Reynolds 2018), the compromised expression lingers on (and is available online to be stumbled across by people who are unaware or outright ignorant). There was no major advantage in conducting an extensive analysis of social media regarding its use of the emergenza migranti metaphor, as recent research has shown that social media in Italy create such a closed and polarised dynamics that debunking false information online, truly 'fake news' is de facto unfeasible (Zollo et al., 2017), in the polarised and 'tribalized' audiences (Orengo, 2005).

\subsection{Emergency discourse: the language issue}

There is no novelty in saying that powerful language shapes the ways in which we think. Lakoff and Johnson (1985) showed the cognitive footprint of metaphors. There are situations though, such as the metaphor of emergenza migranti, that can and do operate as catalyst points to understand the cascading effects of yielding the power of language. Its destructive consequences allow us to identify the explicit connections between political narratives, their journalistic echo-chambers, and the correlation with policies or laws. There is no intention of accusing journalism for its tones and rhetoric, as this is not a polemical pamphlet. There is however the need for reflections on the power that figures of speech have not as stylistic tools but as political tools. The increased usage of emergenza migranti corresponds to the 
introduction of new measures on regulating in equal manner integration or expulsion of nonEuropean residents from Italy in response to migrant flows. According to the extensive DEMIG project on migration policies (2011-2014) - (see full data in DEMIG, 2015b), Italy has seen between 150 and 200 changes to migration policies since 1918 (DEMIG, 2015a). Studying these policies recently for a case-study analysis of their application (Filmer \& Federici, 2018), extensive connections became evident between the emergency narrative of the emergenza migranti and the changes in legislation on politiche di accoglienza (immigration policies).

The most recent legislative processes have been studied in other disciplines (for informative introductions, see Marchetti, 2011; 2014), but it is worth focusing on those of the last two decades and especially those of the last decade as they correlate with the spread of the emergency narrative. Over the century-long engagement with migration policies, only nine of the 200 or so mentioned in DEMIG, were made between 1990 and 2011, which are the years in which politicians saw in the movement of people a growing social concern related to recent historical changes (dissolution of Yugoslavia, 1990s recession, wars in Bosnia-Erzegovina and Kosovo, Iraq, Afghanistan, Sierra Leone, etc). The most restrictive one coming once the measures of the previous governments (themselves guilty of using emergency solutions) had reduced the number of migrant arrivals in Italy by creating sub-humane conditions in detention centres in Libya.

\subsubsection{Fragmented regulatory framework and emergency}

Italy signed the International Covenant on Economic, Social and Cultural Rights promulgated by the United Nations General Assembly UN (1966) in 1967. However, it only ratified it in 1978. However, the first full national law on immigration, which refers to refugees' resettlement, is Act 39 of 28 February 1990 (or the 'Martelli law'). This legislative phase occurred at the beginning of the largest arrivals of migrants into Italy through the Adriatic Sea, 
especially from Albania and former Yugoslavia. This phase saw the recurrent use in journalistic Italian of the synecdoche barconi (fluvial barges) to indicate large groups of migrants crossing to Italy on makeshifts boats to escape poverty and insecurity. The expression lingered in the journalistic variety and continues to be used to depict the instability and danger of sea crossing in unsuitable vessels.

From its inception, the Martelli Law on migration created legislative confusion. Its categories included all typologies of migrants alongside the international category of refugees (Marchetti, 2011; 2014: 53-54). Further clarity arrived following the implementation of European Council's Directives (e.g. 2001/55/EC; ED 2004/83/CE). ${ }^{1}$ In 2001, the Programma nazionale asilo (PNA, National Asylum Plan) led Italian city councils to underwrite a plan with the Office of the United Nations High Commissioner for Refugees (UNHCR) pertaining to the status of asylum seekers and refugees in Italy. This plan was redrafted into Act 189 of 20 July 2002 (the "Bossi-Fini Law") to become the Sistema di protezione per richiedenti di asilo e rifugiati (SPRAR, System for the protection of asylum seekers and refugees), which still underpins the resourcing and management of the Italian reception centres, including support for intercultural communication and mediation. To this legislative amendment corresponded the introduction of the term clandestino (clandestine, illegal immigrant) which entered the journalistic variety as a category to identify groups of peoples much broader than those who could be legally defined as illegal immigrants.

Table 11.1, however, shows the most direct relationship between very recent policy changes and the surrounding political debates. The incremental distribution of emergenza migranti maps on the overall frame to discuss migration trends and to restrict access to migrants.

Table 11.1 Adapted excerpt from the DEMIG POLICY database

[Instert Table 11.1] 


\begin{tabular}{|c|c|c|c|c|c|c|c|}
\hline Year & Policy change & $\begin{array}{l}\text { Policy } \\
\text { area }\end{array}$ & Policy tool & $\begin{array}{l}\text { Target } \\
\text { Group }\end{array}$ & $\begin{array}{l}\text { Target } \\
\text { Origin }\end{array}$ & $\begin{array}{l}\text { Restricti } \\
\text { veness }\end{array}$ & Magnitude \\
\hline 2009 & $\begin{array}{l}2009 \text { Law } 94 \text { or Part II of the } \\
\text { "Pacchetto Sicurezza" } \\
\text { ("Security Package") made it } \\
\text { possible to keep illegal } \\
\text { immigrants up to } 180 \text { days } \\
\text { (previously } 60 \text { days) in so } \\
\text { called Identification and } \\
\text { Expulsion Centres }\end{array}$ & $\begin{array}{l}\text { Border } \\
\text { and } \\
\text { land } \\
\text { control }\end{array}$ & Detention & $\begin{array}{l}\text { Irregular } \\
\text { migrants }\end{array}$ & $\begin{array}{l}\text { All foreign } \\
\text { nationalities }\end{array}$ & $\begin{array}{l}\text { More } \\
\text { restrictive }\end{array}$ & $\begin{array}{l}\text { Minor } \\
\text { change }\end{array}$ \\
\hline 2009 & $\begin{array}{l}2009 \text { Law } 94 \text { or Part II of the } \\
\text { "Pacchetto Sicurezza" } \\
\text { ("Security Package") made } \\
\text { conditions easier for foreigners } \\
\text { graduating from an Italian } \\
\text { university, who now have } 12 \\
\text { months to find a job }\end{array}$ & $\begin{array}{l}\text { Integra } \\
\text { tion }\end{array}$ & $\begin{array}{l}\text { Work } \\
\text { VISA } \\
\text { /permit }\end{array}$ & $\begin{array}{l}\text { Internation } \\
\text { al students }\end{array}$ & $\begin{array}{l}\text { All foreign } \\
\text { nationalities }\end{array}$ & $\begin{array}{l}\text { Less } \\
\text { restrictive }\end{array}$ & $\begin{array}{l}\text { Mid-level } \\
\text { change }\end{array}$ \\
\hline 2011 & $\begin{array}{l}\text { Decree } 181 / 2011 \text { converted } \\
\text { into law } 129 / 2011 \text { - authorizes } \\
\text { the expulsion from Italy of EU } \\
\text { citizens who do not meet the } \\
\text { requirements of the European } \\
\text { Directive on free movement } \\
\text { (targeting Roma community in } \\
\text { Italy). }\end{array}$ & Exit & Expulsion & $\begin{array}{l}\text { Specific } \\
\text { categories }\end{array}$ & EU citizens & $\begin{array}{l}\text { More } \\
\text { restrictive }\end{array}$ & $\begin{array}{l}\text { Mid-level } \\
\text { change }\end{array}$ \\
\hline 2011 & $\begin{array}{l}\text { Decree } 181 / 2011 \text { converted } \\
\text { into law } 129 / 2011 \text { - extended } \\
\text { the maximum duration of } \\
\text { detention of undocumented } \\
\text { foreigners awaiting } \\
\text { deportation from } 6 \text { months to } \\
18 \text { months }\end{array}$ & $\begin{array}{l}\text { Border } \\
\text { and } \\
\text { land } \\
\text { control }\end{array}$ & Detention & $\begin{array}{l}\text { Irregular } \\
\text { migrants }\end{array}$ & $\begin{array}{l}\text { All foreign } \\
\text { nationalities }\end{array}$ & $\begin{array}{l}\text { More } \\
\text { restrictive }\end{array}$ & $\begin{array}{l}\text { Minor } \\
\text { change }\end{array}$ \\
\hline 2011 & $\begin{array}{l}\text { Implementation of } 2009 \text { law - } \\
\text { Introduces Language test (A2 } \\
\text { CEFRL) required to obtain the } \\
\text { long-term residence permit. }\end{array}$ & $\begin{array}{l}\text { Integra } \\
\text { tion }\end{array}$ & $\begin{array}{l}\text { Access to } \\
\text { permanent } \\
\text { residency }\end{array}$ & $\begin{array}{l}\text { All } \\
\text { migrants }\end{array}$ & $\begin{array}{l}\text { All foreign } \\
\text { nationalities }\end{array}$ & $\begin{array}{l}\text { More } \\
\text { restrictive }\end{array}$ & $\begin{array}{l}\text { Major } \\
\text { change }\end{array}$ \\
\hline 2012 & $\begin{array}{l}\text { Presidential Decree } 179 \text { of } 10 \\
\text { March } 2012 \text { - stipulated that } \\
\text { non-EU foreigners intending to } \\
\text { stay longer than one year must } \\
\text { sign a point-based Integration } \\
\text { Agreement with the Italian } \\
\text { State (implementation of } 2009 \\
\text { law) - (A2 Italian language, } \\
\text { civic principles, within } 24 \\
\text { months) }\end{array}$ & $\begin{array}{l}\text { Integra } \\
\text { tion }\end{array}$ & $\begin{array}{l}\text { Language, } \\
\text { housing } \\
\text { and } \\
\text { cultural } \\
\text { integration } \\
\text { programm } \\
\text { es }\end{array}$ & $\begin{array}{l}\text { All } \\
\text { migrants }\end{array}$ & $\begin{array}{l}\text { All foreign } \\
\text { nationalities }\end{array}$ & $\begin{array}{l}\text { More } \\
\text { restrictive }\end{array}$ & $\begin{array}{l}\text { Major } \\
\text { change }\end{array}$ \\
\hline 2018 & $\begin{array}{l}\text { Decree } 113 \text { of } 5 \text { October } 2018 \\
\text { restricts the definition of } \\
\text { asylum seekers and imposed } \\
\text { reductions on times for } \\
\text { assessment of application, as } \\
\text { well as closing the CARAs } \\
\text { (Reception centres for asylum } \\
\text { seekers). }\end{array}$ & $\begin{array}{l}\text { Border } \\
\text { and } \\
\text { land } \\
\text { control }\end{array}$ & $\begin{array}{l}\text { Detention, } \\
\text { deportatio } \\
\mathrm{n} \text {, and } \\
\text { repatriatio } \\
\mathrm{n}\end{array}$ & $\begin{array}{l}\text { All } \\
\text { migrants }\end{array}$ & $\begin{array}{l}\text { All foreign } \\
\text { nationalities }\end{array}$ & $\begin{array}{l}\text { More } \\
\text { restrictive }\end{array}$ & $\begin{array}{l}\text { Major } \\
\text { change }\end{array}$ \\
\hline
\end{tabular}

Source: The table adapts (DEMIG, 2015a) examples relevant to Italy from the DEMIG database integrating data on the most recent policy revisions. 
From the DEMIG classification and coding of the migration policies, two features are particularly relevant to this discussion: the policy area and the target group (for a detailed explanation of the coding, see De Haas, Natter, \& Vezzoli, 2015). Policy area refers to 'what' is the core focus of the policy, whilst the target group refers to 'who', i.e. the groups who are affected by the policy. The magnitude of the policy is an indication of the degree of legislative change applied by the policy to the existing legal framework; in this perspective, the case of the 2009 changes, the security (anti-migrant) revision is a minor change and revision for graduates is the second most important category of change in the DEMIG approach. These details are important because they show how the legislative changes map on the aggressive political debate of 2009-2011 and resurface as soon as these subterranean debates in the fringes of right-wing movements became the flagship policies of the right-wing coalition government in power since 2018 .

\subsubsection{The system 'works because it's an emergency'}

These legislative and policy actions regulate the management of the Centri di Accoglienza per Richiedenti di Asilo (CARA, Reception centres for asylum seekers) and pertain to SPRAR's ordinary management, whereas the Centri di Accoglienza Straordinari (CAS, Extraordinary Refuge Centres) were set up in 2014 thus marking the need for additional, hence 'extraordinary', centres operated by local authorities to deal with the increased migrant flows. Marchetti (2014: 68) discusses the mindset behind this duplicate system of reception centres with the introduction of the CAS, whose creation was also driven to prove that the Italian government was working without support, as the EU had organized only uncoordinated efforts to support those member states, like Italy, who had seen an enormous increase in migrant arrivals. For the purpose of this chapter, the very name of the centres, which are straordinari, 
shows the continued perception of the state of emergency, aligned with the figurative language of the emergenza migranti.

The discourse has affected also provision of language services to migrants. The perception of people displacement as an emergency is reflected in the ways in which established academic centres of excellence in pedagogy and training in public service interpreting (Trieste, Bologna-Forlì, Pisa) and their training systems were excluded by a major attempt to devise a policy to establish a national threshold for the professionalisation of intercultural mediators. Their programmes and practices were not consulted by the Italian Ministry of Interiors set up a special commission, funded by the EU, to organize language and culture mediation services. In theory, the legislative push for defining the professional status of mediatori linguistici or mediatori culturali (language or culture mediators) dates from 2009, but a further push came from the perceived emergenza. For speakers who need interpreting and translation from languages that are not converted in formal, academic education in translation and interpreting, there is often an issue of recruitment (besides obvious issues of quality). Hence reflections on intercultural mediators, coming from practices of integration in the schooling systems (mediatori culturali) rather than from public services interpreting approaches and research seemed to prevail.

The prevalence of the approach towards 'integration' rather than language service provision can be discussed in positive terms (e.g. gradual integration by limiting language barriers for the migrants) as much as in negative terms (e.g. there is no money to spend on providing suitable support to intercultural communication, or even worse: immigrants are left to their own devices). These debates are beyond the scope of this chapter, but they are not to be underestimated. Concerning the prevalent sense of urgency determined by the emergenza narrative, the institutional approach seemed to move to the application of the language policies set out by the Presidential Decree (DPR) 179 of 14 September 2011. Entitled 'Regolamento 
concernente la disciplina dell'accordo di integrazione tra lo straniero e lo Stato' (Regulation regarding the integration agreement between a foreign person and the State), the DPR was enacted in 2012 and it lays out the legal principles that regulate language use in relation to migration. According to the DPR 179/2011, the Italian State and non-EU foreign residents willing to integrate into the Republic (be they economic migrants, asylum seekers, or refugees) enter into a contract, termed the Integration Agreement (Di Muzio, 2012, p. 8). The DPR creates a point-based system to obtain the permit and a pathway to integration; it foresees the potential allocation (art.2, par.2) of "credits" for the applicants' competence in the Italian language, culture, and knowledge of the institutions of the Republic of Italy in compliance with art. 5 of Act 286 of 25 July 1998, regulating the status of immigrants in Italy. The DPR therefore presupposes a phased emancipation from the reliance on translators, interpreters, and cultural, or linguistic, mediations it henceforth anticipates them as being needed upon arrival in Italy.

The provision of translation and interpreting services is perceived as part of the initial phase of interactions between migrants and Italian institutions. Gradual acquisition of the language is intended in the legal framework as intertwined with socio-cultural integration, thus incorporating provision for issues such as education, employment, and health in the point-based pathway to integration. In terms of language policy, its long-term focus is equally its strength and fatal flaw: the Integration Agreement leads non-EU migrants to EU citizenship though a direct route to the Italian VISA, which can be perceived in the EU as a backdoor pathway and a problem of securitization (Guild, 2014a, 2014b). Furthermore, with its focus on long-term, permanent migrants, it could be reasonably argued that the policy is potentially irrelevant when it comes to addressing the sudden increase of 'humanitarian immigrants' (using OECD terminology) experienced in the 6 years following its 2012 ratification. 
If social and language needs connected to the Integration Agreement stayed more or less the same over the first two years after its ratification, Italy then indeed saw a 'sharp rise in humanitarian immigration', however it 'coincided with a wider picture of overall immigration reduction (21\% in total)' (OECD, 2017, p. 16; 2018). The change to humanitarian integration was conflated in the political framing underlying the emergenza migranti narrative. In turn, the legislative flexibility on community-specific contexts becomes a lack of clarity and support. When the number of humanitarian migrants increased suddenly, it generated pressure on the reception system as a whole. The increase in numbers and their needs raised barriers for humanitarian migrants to communicate with the Italian institutions and vice versa (for a case study, see Filmer and Federici 2018). Language needs for non-permanent migrants in the already-overstretched system in place for asylum seekers and VISA applicants increased following the regulatory changes, which show up the overall lacunae of the Italian, as well as European, immigration policies in the response to the linguistic emergencies, whereby the system according to intercultural mediators involved works only 'because it's an emergency' (see Filmer and Federici 2018: 234).

\subsubsection{Fragmented intercultural communication policies}

In 2009, those involved in intercultural communication with migrants became formally called and recognized as intercultural mediators. Their role was to support changes in social expectations recorded in the previous decade. Morniroli et al. (2007: 5) considered migrant flows towards Italy as no longer embedded in notions of emergency but as already 'organised and structured' phenomena belonging to the socio-economic composition of Italian society. From this perspective, the rise of demand for such services as intercultural mediation, interpreting, and translation across the Italian peninsula are due to the country's socio-cultural transformations. The Italian definition of intercultural mediators draws from research in the 
early 2000s in relation to language support in the classroom and the legal term became the most common after the DPR179/2011 was ratified. The statutory mechanisms of DPR179/2001 for language provision are disseminated in the dedicated portal entitled Integrazione Migranti Vivere e lavorare in Italia (Migrant Integration: Working and living in Italy) ${ }^{3}$. The portal summarises how the legal framework organizes the professional role of intercultural mediators. These figures cover a variety of communicative needs that range from first response to asylum seekers, refugees, and VISA applicants' support. Although it is true that training in intercultural mediation ought to engage with the latest societal needs (Kelly, 2017), the sudden obligation for autochthonous (often economically deprived) communities to integrate newcomers in uncontrolled and disorganized processes is a consequence of the political narrative filtering into institutional practices, and in turn cementing the public's concerns and fears around a phenomenon that is not a state of emergency from the perspective of the accommodating host society but a dramatic state of displaced people and a complicated intercultural crisis.

A 2014 report offers the most recent figures collected and shows how there is demand and intent to establish a training pathway to prepare intercultural mediators to deal with the changing needs of migrants in their pathways to integration (Melandri et al., 2014). Within the legislative framework established by the emergenza, the 20 regions of Italy could define professional intercultural mediators in as many as 20 different ways. The pervasive rhetoric of emergency seems to influence the ways in which the most significant voices of translation and interpreting training programmes in Italy were excluded from the public consultation towards defining the profiles of intercultural mediators. Urgency once again seems to prevail over planning. Associated by the law to reflect community-specific needs at local level, such flexibility impedes local authorities from deploying established and efficient practices developed elsewhere so as to maximize resources. Arguably, such application of the law to 
training policies for intercultural mediators attests to embedded political disregard towards the wider societal training needs as much as existing literature was virtually ignored in the plans to support formal training of intercultural mediators (including the works by Angelelli, 2004; Corsellis, 2008; Hale, 2007, 2011). The metaphor of emergenza migranti achieved exactly this result and with the Decree of Law 113/2018, it achieved its greatest victory as Italy has created a policy of closure in favour of adopting migration polices from all the countries who signed up the agreements on asylum applications. It also means that the focus as shifted only to one category of migrants, the humanitarian migrant seeking asylum only within those under ‘international protection’ (art.12, par. 4).

\subsection{Concluding remarks}

In Italy, the metaphor of emergenza migranti has taken a life of its own, accentuating political discontent and unrest in Italy. In an interview given in September to BBC, former Minister of the Interior for the previous government, Mr Marco Minniti, who organized in 2017 the controversial agreement with Libya to control dangerous crossing towards Southern Italian harbours, analysed the reasons for the electoral victory of populist parties over the centre-left groups to which he belongs. His analysis of the election results, clearly from the side of the losers, engages with the issue of migration, attributes the loss to the delay of his party to address that issue, which caused a sense of fear and anger. Minniti explains 'We lost the election for two reasons $[\ldots]$. We did not respond to two feelings that were very strong: anger and fear. We lost contact with a big part of public opinion' (Reynolds, 2018). Audiences had been listening for almost a decade of framing of the emergenza migranti, which in fact comes in the interview with Minniti:

Mr Salvini [right-wing, Northern League, current Minister of the Interior] has won headlines by turning away foreign-flagged rescue boats -and by asserting that he's the politician who's 
finally got a grip on migration. But in terms of reducing migrant numbers, it's Marco Minniti who's had by far the most impact -not Matteo Salvini.

'The point is this. Italy managed to show Europe and the world that you can manage migration, keeping two principles in mind: humanity and security. Now we're in another phase. There is no migrant emergency in Italy,' [Minniti] replies.

In this interview, Minniti's words underline his bitterness in having to prove what Italy could do about the migrant flows in isolation, unaided by the EU institutions - a common refrain accepted by all Italian parties without being challenged. The United Nations Support Mission in Libya released the full grim details of the Libyan detentions centres, in its report entitled Desperate and Dangerous (2018).

By looking at a figure of speech that has influenced not only political and social debates, through its frequency in the journalistic variety of Italian, there are indications that this powerful metaphor entrenched the perception of the global phenomena of migration into a reductive notion of emergency. This notion then so coloured the political debate in Italy to be reflected in flimsy and confused legislative approaches oscillating between punishment and integration. In this context, the notion of emergency came to overshadow a problem that needs to be discussed as a social crisis. As such, the crisis needs to be addressed with long-term plans and articulated, not punitive, solutions: it needs long-term determination, motivations and ingenuity so as to imagine and develop alternative ways to deal with migrations. For its geography, Italy has a role to play whilst protecting all of its residents and receiving asylum seekers, temporary refugees, as well as social and economic migrants. It also has demands from the European Union and a role to play to steer immigration and integration policies. In other words, Italy ought to have looked at ways to unshackle itself from the emergenza migranti. The need for reception centres and revised policies to deal with transmigrants (see discussion in Chapter 2), people who arrive in Italy to reach their intended countries of destination, was not an emergency; the situation was handled so that it managed to hide a complex crisis and partial legislative restrictions replaced socio-political solutions for the long-term. 


\section{References}

AGCOM. (2018). Rapporto sul consumo di informazione. Rome and Naples: AGCOM. Available online: $\quad$ https://www.agcom.it/documents/10179/9629936/Studio-

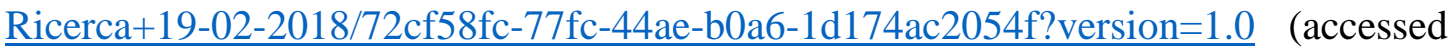
21 March 2019).

Angelelli, C. V. (2004). Medical interpreting and cross-cultural communication. Cambridge: Cambridge University Press.

Billiani, F. (2007/2014). 'Assessing Boundaries-Censorship and Translation.' In F. Billiani (ed.), Modes of Censorship: National Contexts and Diverse Media (pp. 1-25). London and New York, NY: Routledge.

Bonomi, I. (2002). L'italiano giornalistico. Dall'inizio del '900 ai quotidiani on line. Florence: Franco Cesati Editore.

Bunn, M. (2015). 'Reimagining Repression: New Censorship Theory and After.' History and Theory 54: 25-44.

Clerwall, C. (2014). 'Enter the robot journalist: Users' perceptions of automated content.' Journalism Practice 8(5): 519-531.

Corsellis, A. (2008). Public service interpreting: The first steps. Basingstoke and New York, NY: Palgrave Macmillan.

De Haas, H., Natter, K., \& Vezzoli, S. J. C. M. S. (2015). 'Conceptualizing and measuring migration policy change.' Comparative Migration Studies 3(1): 15.

DEMIG. (2015a). demig-policy-database_italy_version-1-3. In DEMIG POLICY, version 1.3, Online Edition. Oxford: International Migration Institute, University of Oxford. Available online: http://www.migrationdeterminants.eu/ (accessed 21 March 2019).

DEMIG. (2015b). DEMIG POLICY, version 1.3, Online Edition. Oxford: International Migration Institute, University of Oxford. Available online: 
https://www.imi.ox.ac.uk/data/demig-data/demig-policy-1/download-the-data/demigpolicy-data-downloads (accessed 21 March 2019).

Di Muzio, G. (2012). Italy. Focus Migration Country Profile 23. Available online: http://www.bpb.de/gesellschaft/migration/laenderprofile/145671/migrationspolitik (accessed 21 March 2019).

Eco, U. (1971). 'Guida all'interpretazione del linguaggio giornalistico.' In V. Capecchi \& M. Livolsi (eds.), La stampa quotidiana in Italia (pp. 335-377). Milan: Bompiani.

Federici, F. M. (2011). 'Silenced Images: the Case of Viva Zapatero!' In R. Wilson \& B. Maher (eds), Words, Sounds, Images (pp. 139-157). London: Continuum.

Federici, F. M. (2016). 'Introduction: A state of emergency for crisis communication.' In F. M. Federici (ed.), Mediating Emergencies and Conflicts. Frontline Translating and Interpreting (pp. 1-29). New York, NY: Palgrave Macmillan.

Filmer, D. (2018). 'War of the Words: Dialectics and discourse on the "migrant crisis" and “Islamic terrorists” in British and Italian newspapers.' InVerbis 1: 165-186.

Filmer, D., \& Federici, F. M. (2018). 'Mediating Migration Crises: Sicily and the Languages of the Despair.' European Journal of Language Policy 10(2): 229-253.

FNSI. (2014). Charter of Rome. Rome: FNSI. Available online: https://mediacompolicy.univie.ac.at/wp-content/uploads/2016/06/CODE-ANDGLOSSARY-ENGLISH.pdf (accessed 21 March 2019).

Guild, E. (2014a). 'Conflicting identities and securitisation in refugee law: Lessons from the EU.' In S. Kneebone, D. Stevens, \& L. Baldassar (eds), Refugee protection the role of law: Conflicting identities (pp. 151-173). London and New York, NY: Routledge.

Guild, E. (2014b). 'Migration, security and European citizenship.' In E. F. Isin \& P. Nyers (eds.), Routledge Handbook of Global Citizenship Studies (pp. 418-426). London and New York, NY: Routledge. 
Hale, S. (2007). Community interpreting. Houndsmill, Basingstoke and New York, NY: Palgrave MacMillan.

Hale, S. B. (2011). 'Public service interpreting.' In K. Malmkjær \& K. Windle (eds), The Oxford Handbook of Translation Studies (pp. 343-356). London and New York, NY: Routledge.

Horowitz, J. (2017). 'Italy, Bracing for Electoral Season of Fake News, Demands Facebook's Help.' The New York Times, International edition. 25 Nov 2017. Available online: https://search.proquest.com/docview/1968183526?accountid=14511 (accessed 21 March 2019).

Lakoff, G., \& Johnson, M. (1985). Metaphors We Live By. London and Chicago, IL: University of Chicago Press.

Lorusso, A. M., \& Violi, P. (2015). Semiotica del testo giornalistico (2nd ed.). Rome and Bari: Laterza.

Marchetti, C. (2011). 'Assistiti o segregati? I grandi centri per richiedenti asilo in Italia.' La società degli individui 41(14): 57-70.

Marchetti, C. (2014). 'Rifugiati e migranti forzati in Italia. Il pendolo tra "emergenza" e “sistema”.' REMHU-Revista Interdisciplinar da Mobilidade Humana 22(43): 53-70.

McKnight, J., \& Coronel, J. C. (2017). 'Evaluating Scientists as Sources of Science Information: Evidence From Eye Movements.' Journal of Communication 67(4): 565585.

Montgomery, M. (2008). An introduction to language and society. London and New York, NY: Routledge.

Nardelli, A., \& Silverman, C. (2017). 'One Of The Biggest Alternative Media Networks In Italy Is Spreading Anti-Immigrant News And Misinformation On Facebook.' BuzzFeed News. 2 November 2017. Available online: https://www.buzzfeed.com/albertonardel 
$\underline{\text { li/one-of-the-biggest-alternative-media-networks-in-italy-is?utm term=.qqXDPq }}$

QgoL\#.nlogYlwb91 (accessed 21 March 2019).

Natale, S. (2016). 'There are no old media.' Journal of Communication 66(4): 585-603.

Neander, J. and R. Marlin (2010). 'Media and Propaganda.' Global Media Journal 3(2): 6782. Available online: https://core.ac.uk/download/pdf/26945870.pdf (accessed 21 March 2019)

OECD. (2017). International Migration Outlook 2017. Paris: OECD.

OECD. (2018). International Migration Outlook 2018. Paris: OECD.

Orengo, A. (2005). 'Localising News: Translation and the 'Global-national' Dichotomy.' Language and Intercultural Communication 5(2): 168-187.

Pescaroli, G., \& Alexander, D. E. (2015). 'A definition of cascading disasters and cascading effects: Going beyond the “toppling dominos" metaphor.' planet @ risk 3(1): doi:https://planet-risk.org/index.php/pr/article/view/208.

Reynolds, J. (2018). 'Marco Minniti: The man who cut the migrant flow to Italy.' BBC News. Available online: https://www.bbc.co.uk/news/world-europe-45575763 (accessed 21 March 2019).

Slavtcheva-Petkova, V. (2016). 'Are Newspapers' Online Discussion Boards Democratic Tools or Conspiracy Theories' Engines? A Case Study on an Eastern European "Media War".' Journalism \& Mass Communication Quarterly 93(4): 1115-1134.

UNHCR. (2017). Global Trends. Forced Displacement in 2017. Geneva: United Nations High Commissioner for Refugees. Available online: https://www.unhcr.org/5b27be547.pdf (accessed 21 March 2019).

UNHCR. (2019). Desperate and Dangerous: Report on the human rights situation of migrants and refugees in Libya. Geneva: United Nations High Commissioner for Refugees. 
Available online: https://www.ohchr.org/Documents/Countries/LY/LibyaMigrationR eport.pdf (accessed 21 March 2019).

Wakefield, A. J., Murch, S. H., Anthony, A., Linnell, J., Casson, D., Malik, M., . . Harvey, P. (1998). RETRACTED: 'Ileal-lymphoid-nodular hyperplasia, non-specific colitis, and pervasive developmental disorder in children.' The Lancet 351(9103): 637-641.

Zelizer, B. (2015). 'Terms of Choice: Uncertainty, Journalism, and Crisis.' Journal of Communication 65(5): 888-908.

Zelizer, B., \& Allan, S. (2010). Keywords in News and Journalism Studies. Maidenhead, UK: Open University Press.

Zollo, F., Bessi, A., Del Vicario, M., Scala, A., Caldarelli, G., Shekhtman, L., . . . Quattrociocchi, W. (2017). 'Debunking in a world of tribes.' PLOS ONE 12(7): e0181821. doi:https://doi.org/10.1371/journal.pone.0181821. 